\title{
PENGGUNAAN ARTIFICIAL NEURAL NETWORK UNTUK PENGENALAN POLA: PENERIMAAN DAN PENDAPATAN PETANI TEBU
}

\author{
Cungki Kusdarjito ${ }^{1}$ dan Any Suryantini ${ }^{2}$
}

Universitas Janabadra, Fakultas Pertanian, Jalan Tentara Rakyat Mataram 55-57 Yogyakarta Universitas Gadjah Mada, Fakultas Pertanian, Jl Flora, Bulaksumur, Yogyakarta Email: ckusdarjito@janabadra.ac.id

\begin{abstract}
ABSTRAK. Selama ini sebagian besar analisis dalam bidang pertanian, khususnya agribisnis dan sosial ekonomi pertanian menggunakan pendekatan ekonometrika dengan mendasarkan pada asumsi "linieritas". Pendekatan ini memberikan keunggulan dalam analisis ekonomi, seperti elastistas, return to scales, ataupun analisis fungsi permintaan dan penawaran dapat diketahui dengan mudah. Meskipun demikian, saat ini disadari bahwa permasalahan dalam bidang pertanian tidak sesederhana yang diasumsikan. Fungsi yang dianalisis mungkin merupakan fungsi polynomial. Beberapa variabel mungkin tidak dapat didefinisikan dengan jelas, khususnya variabel sosial. Oleh karena itu, penggunaan soft computing seperti model saraf buatan (artificial neural network), genetic algorithm, fuzzy logic mulai banyak dipergunakan untuk memecahkan berbagai persoalan yang bersifat non-linier, hazy dan subyektif. Berkaitan dengan hal tersebut, tulisan ini memberikan ilustrasi penggunaan model saraf buatan dalam bidang pertanian dengan mengambil kasus pada tanaman tebu. Perhitungan dilakukan dengan menggunakan multilayers networks sebanyak empat lapis dan proses belajar menggunakan algoritma back propagation. Proses pembelajaran dilakukan sampai terjadi overtraining untuk memetakan pola hubungan faktor penentu penerimaan dan pendapatan petani tebu. Hasil yang diperoleh menunjukkan bahwa biaya-biaya seperti sewa lahan, bibit, pestisida dan tenaga kerja memiliki kontribusi yang besar dalam mempengaruhi penerimaan dan pendapatan petani. Biaya sewa lahan yang tinggi dengan penggunaan biaya kerja yang rendah akan menekan pendapatan petani sehingga usaha tani tebu harus diusahakan secara intensif. Selain itu, biaya modal sendiri cenderung lebih menekan pendapatan dibandingkan dengan modal pinjaman.
\end{abstract}

Kata-kata kunci: neural network, linearitas, polynomial

\section{ARTIFICIAL NEURAL NETWORK FOR PATTERN RECOGNITION: REVENUE AND INCOME OF SUGARCANE FARMERS}

ABSTRACT Most analyses in agribusiness uses econometrics approach since it excels in economics interpretation such as elasticities, return to scales, or supply and demand analysis. Moreover, majority of models in agribusiness is assumed to be linear. Yet, in real life most of the problems in agribusiness are complex, mostly non-linier (polynomial) and sometime hazy, especially for the social variables. Therefore, soft computing such as artificial neural network, fuzzy logic, genetic algorithm, is more appropriate to handle such problems. Hence, this paper illustrates the impacts of input, reflected as cost, on revenue and income of the sugarcane farmers using multilayer artificial neural networks. The learning algorithm used in this research is back propagation. The learning process is carried out 50.000 times until the model overtrained and the pattern can be derived. The results indicated that the cost for renting land, seed (ratoon and planted combined), pesticide and labor have major contribution on farmer's incomes and revenues. High proportion of cost for renting land with lower labor cost reduced farmers' income, which indicated that sugarcane should be cultivated intensively. Meanwhile, farmers with higher 'internal' loan have greater pressure on their income compare to those who have external loans.

Keywords: neural networks, linear, polynomial 


\section{PENDAHULUAN}

\section{Pendekatan Model Jaringan Saraf Buatan}

Model jaringan saraf buatan, yang terinspirasi dari ilmu biologi seperti bekerjanya saraf manusia di dalam memecahkan masalah. Model ini dapat menghitung atau memprediksi berdasarkan proses informasi dan identifikasi pola yang diolah oleh jaringan saraf buatan tersebut (Tan, 1997).

Model jaringan sarafbuatan merupakan model perhitungan paralel dengan sejumlah prosesor saling terhubung seperti halnya pada neuron dan mempunyai kemampuan untuk belajar melalui proses trial and error (Carpio \& Hermosilla, 2000). Krose \& van der Smagt (1996) mengemukakan bahwa model jaringan saraf buatan mempunyai beberapa karakteristik seperti kemampuan untuk belajar, melakukan generalisasi, klasifikasi dan kategorisasi. Perhitungan yang dilakukan pada model jaringan saraf buatan bersifat paralel. Jain et al. (1996) mengemukakan bahwa model jaringan saraf buatan pada umumnya dipergunakan untuk pengenalan pola (pattern recognition), pengelompokan data (clustering / categorization), pendugaan fungsi (function approximation), peramalan (prediction / forecasting), optimasi (optimization) dan kontrol.

Generasi pertama model jaringan saraf buatan dimulai dari kerja McCulloh dan Pitts pada tahun 1943. Model yang dikembangkan merupakan penyederhanaan cara kerja jaringan saraf biologis. Meskipun demikian, perkembangan model jaringan saraf buatan mengalami stagnasi semenjak tahun 1969 setelah Minsky dan Papert menunjukkan adanya kelemahan mendasar pada model jaringan saraf buatan, yaitu ketidakmampuan model jaringan saraf buatan (yang dinamakan sebagai Perceptron) untuk melakukan generalisasi pada kasus XOR (exclusive OR).

Perkembangan model jaringan saraf buatan kembali memperoleh momentum pada awal tahun 1980-an seiring dengan kemajuan perkembangan perangkat keras komputer dan ditemukannya algoritma yang dapat mengatasi masalah yang dikemukakan oleh Minsky dan Papert dengan munculnya metode error back propagation. Adanya algoritma error back propagation memungkinkan penerapan model jaringan saraf buatan yang terdiri dari beberapa lapis (multilayer). Selain itu, penggunaan multilayer memungkinkan model jaringan saraf buatan melakukan pendugaan fungsi yang bersifat non-linier (Jain et al., 1996).

Model multilayer pada umumnya terdiri dari input layer, hidden layer dan output layer. Karena pada input layer tidak dilakukan proses perhitungan, maka suatu model jaringan saraf buatan yang terdiri dari input layer, satu hidden layer dan output layer disebut sebagai model jaringan saraf buatan dua lapis (two layers) (Krose \& van der Smagt, 1996, Jain et al, 1996, Sima, 1998). Proses penyusunan model jaringan saraf buatan melibatkan tiga tahapan: (1) penentuan struktur structure) yaitu arsitektur atau bentuk (topologi) model jaringan saraf buatan, (2) encoding (enkoding) yaitu metode yang dipergunakan untuk merubah nilai bobot (weight), misalnya back-propagation atau Hebbian learning dan (3) Recall yaitu proses pemanggilan kembali informasi dari model jaringan saraf buatan jika pada model jaringan saraf buatan diberikan suatu nilai input tertentu (Krose \& van der Smagt, 1996).

\section{METODE \\ Model Jaringan Saraf Buatan}

Model jaringan saraf buatan yang dipergunakan dalam tulisan ini adalah multilayer perceptron dengan pendekatan backpropagation. Pada model jaringan saraf buatan, setiap unit yang berhubungan dengan unit lain akan memberikan kontribusinya terhadap unit yang berdekatan. Total input terhadap unit $\mathrm{k}$ dapat didefinisikan sebagai penjumlahan tertimbang ditambah dengan nilai offset (bias) yaitu:

$$
s_{k}(t)=\sum_{j} w_{k}(t) y_{j}(t)+\theta_{k}(t)
$$


Selanjutnya, pengaruh total input terhadap proses aktivasi terhadap unit $y_{t}(t+1)$ ditentukan oleh suatu fungsi $F_{k}$ yang akan menghasilkan suatu nilai baru dari total input $s_{k}(t)$ dan nilai aktivasi $y_{k}(t)$ pada saat ini, yaitu

$y_{k}(t+1)=F_{k}\left[y_{k}(t), s_{k}(t)\right]$

sedangkan error function didefinisikan sebagai:

$E=\sum_{p} E^{p}=\frac{1}{2} \sum_{p}\left(d^{p}-y^{p}\right)^{2}$

dimana $d^{p}$ adalah nilai yang diharapkan sedangkan $y^{p}$ adalah nilai aktivasi. Aktivasi (pada output) adalah suatu fungsi yang dapat diturunkan dari total input, yaitu

$y_{k}^{p}=F\left(s_{k}^{p}\right)$

$s_{k}^{p}=\sum_{j} w_{k} y_{j}^{p}+\theta_{k}$

Prosedur LMS (Least Square Method) pada dasarnya berusaha untuk mencari nilai bobot $w$ yang akan meminimalkan fungsi kesalahan (error function) dengan mempergunakan metode yang disebut dengan gradient descent.

Pada model jaringan saraf buatan, untuk mengetahui nilai $\mathrm{E}$ yang terkecil digunakan nilai RMS (root mean square). Untuk mengetahui nilai RMS, data yang akan dianalisis dibagi menjadi dua, yaitu data untuk training bagi model jaringan saraf buatan (training set) dan data untuk pengujian (test set). Pada umumnya, nilai RMS untuk training set akan terus menurun dengan bertambahnya jumlah iterasi sedangkan nilai RMS untuk test set akan menurun sampai jumlah iterasi tertentu kemudian setelah itu nilai RMS untuk test set akan kembali menaik. Kenaikan nilai RMS pada test set menunjukkan bahwa kemampuan generalisasi model jaringan saraf buatan mulai berkurang.

\section{Jenis dan Sumber Data}

Jenis data yang dipergunakan untuk penelitian ini adalah data primer sedangkan sumber data adalah petani tebu di Kabupaten Bantul dan Sleman, Daerah Istimewa Yogyakarta, dengan jumlah responden sebanyak 64 orang. Pengumpulan data dilakukan pada bulan Juni sampai dengan September 2012. Analisis dilakukan untuk membandingkan perhitungan yang diperoleh dari regresi linier dan model saraf buatan. Variabel bebas terdiri dari komponen biaya produksi tebu dan dinyatakan dalam rupiah sedangkan variabel tidak bebas (output) terdiri penerimaan dan pendapatan petani. Berhubung data harga relatif tidak banyak berfluktuasi maka variabilitas input lebih banyak dipengaruhi oleh kuantitas input yang digunakan.

\section{Metode Perhitungan}

Perhitungan pertama mempergunakan analisis regresi linier. Selanjutnya, dengan mempergunakan data yang sama dilakukan perhitungan dengan mempergunakan model saraf buatan yang terdiri dari empat lapis (layers), tidak termasuk input layer. Adapun metode pembelajaran yang dipergunakan adalah back propagation. Penggunaan beberapa hidden layers dalam analisis ini untuk mengetahui hubungan antarvariabel yang bersifat non-linier. Iterasi proses perhitungan dilakukan sebanyak 50.000 kali, meskipun proses pembelajaran (learning) sebenanya dapat dihentikan pada iterasi ke 5.000 karena RMS error untuk training set mulai bergerak naik setelah iterasi ke 5.000 (lihat Gambar 1). Penghentian saat iterasi mencapai 5.000 kali lebih sesuai untuk melakukan proses generalisasi. Jumlah test set ditentukan secara acak sebanyak 15 data.

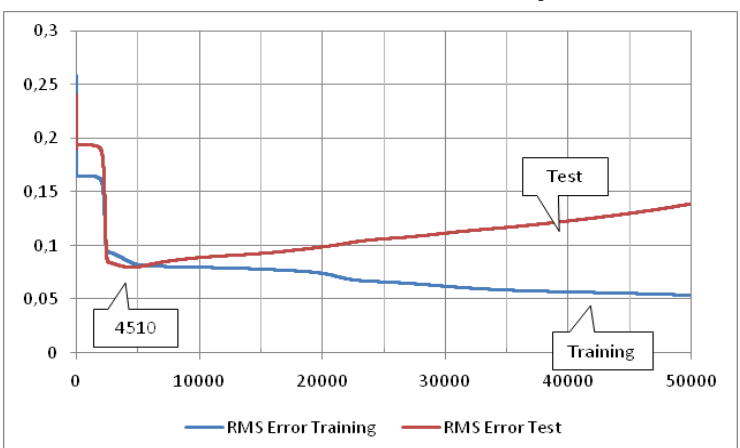

Gambar 1. Nilai Root Mean Square (RMS) Training dan Error Set 
Setelah proses learning selesai, selanjutnya dilakukan recall melalui model saraf buatan beserta bobot (weight) yang diperoleh dari hasil iterasi sebanyak 50.000 kali. Proses recall dilakukan dengan "memperbanyak" data dari 64 menjadi 10.000 data untuk setiap variabel. Dalam penelitian ini terdapat tujuh variabel yaitu biaya sewa lahan, biaya pupuk, biaya bibit, biaya pestisida, bunga pinjaman, biaya tenaga kerja (biaya eksplisit) dan bunga modal sendiri (biaya implisit). Total data untuk variabel bebas yang di-generate model adalah sebanyak 490.000 buah.

\section{HASIL DAN PEMBAHASAN}

\section{Perbandingan Hasil Perhitungan Analisis Regresi Linier dan Model Saraf Buatan}

Pada dasarnya model saraf buatan adalah model yang bersifat black box, yaitu peneliti "tidak dapat" menentukan pengaruh variabel bebas (input) dengan variabel tak bebas (output) secara eksplisit seperti halnya pada analisis regresi. Salah satu cara untuk mengatasi kelemahan ini adalah dengan menentukan kontribusi masing-masing variabel input terhadapat variabel output. Model saraf buatan yang hanya terdiri dari input dan output dan tidak memiliki hidden layers pada dasarnya sama dengan analisis regresi linier. Meskipun demikian, model saraf buatan sangat baik dipergunakan untuk mengenali pola maupun sebagai penduga fungsi yang bersifat non-linier.

Adapun hasil analisis dengan mempergunakan model regresi dan saraf buatan disajikan pada Tabel 1 berikut:

Hasil analisis dengan mempergunakan model saraf buatan menunjukkan bahwa sewa lahan, bibit, pestisda dan tenaga keja memiliki kontribusi yang besar baik pada penerimaan dan pendapatan petani. Meskipun hasil yang diperoleh dari analisis dengan mempergunakan model saraf buatan menunjukkan (biaya) pengadaan bibit memiliki kontribusi yang besar terhadap pendapatan petani tebu, akan tetapi hasil dari analisis regresi (lihat Tabel 2) menunjukkan bahwa besarnya biaya bibit tidak mempunyai pengaruh yang signifikan dalam meningkatkan pendapatan petani. Meskipun demikian, pengadaan bibit cukup signifikan dalam menurunkan penerimaan petani.

Tabel 1. Kontribusi Input Model Saraf Buatan (\%)

\begin{tabular}{|c|c|c|}
\hline \multicolumn{2}{|c|}{ Output Input(BiayaRp) } & Kontribusi \% \\
\hline \multirow{7}{*}{ 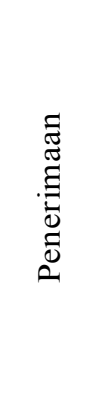 } & Sewa Lahan & 27,05 \\
\hline & Bunga Pinjaman & 3,68 \\
\hline & BIBIT & 13,97 \\
\hline & PUPUK & 4,87 \\
\hline & PESTISIDA & 14,4 \\
\hline & TENAGA KERJA & 28,77 \\
\hline & BUNGA MODAL SENDIRI (Rp) & 7,26 \\
\hline \multirow{7}{*}{ 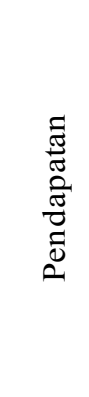 } & Sewa Lahan & 28,18 \\
\hline & Bunga Pinjaman & 4,52 \\
\hline & BIBIT & 18,1 \\
\hline & PUPUK & 3,17 \\
\hline & PESTISIDA & 14,75 \\
\hline & TENAGA KERJA & 27,24 \\
\hline & BUNGA MODAL SENDIRI (Rp) & 4,04 \\
\hline
\end{tabular}

Tabel 2. Hasil Analisis Regresi

\begin{tabular}{|c|c|c|}
\hline Output & Input ( & \\
\hline \multirow{10}{*}{ 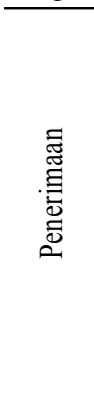 } & Sewa Lahan & $1,88 \mathrm{E}+00 * * *$ \\
\hline & Bunga Pinjaman & $3,32 \mathrm{E}-01$ \\
\hline & BIBIT & $-4,46 \mathrm{E}-01$ \\
\hline & PUPUK & $-4,45 \mathrm{E}-01$ \\
\hline & PESTISIDA & $7,96 \mathrm{E}+00 *$ \\
\hline & TENAGA KERJA & $2,51 \mathrm{E}+00 * * *$ \\
\hline & \multicolumn{2}{|c|}{ BUNGA MODAL SENDIRI (Rp)-2,98E+00 } \\
\hline & Konstan & $1,12 \mathrm{E}+07$ \\
\hline & $\mathrm{R}^{2}$ & 0,9563 \\
\hline & & $8,83 \mathrm{E}-01$ \\
\hline \multirow{9}{*}{ 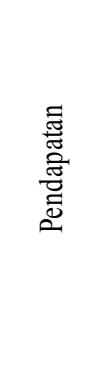 } & Sewa Lahan & \\
\hline & Bunga Pinjaman & $-6,68 \mathrm{E}-01$ \\
\hline & BIBIT & $-1,45 \mathrm{E}+00^{*}$ \\
\hline & PUPUK & $-1,45 \mathrm{E}+00^{*}$ \\
\hline & PESTISIDA & $6,96 \mathrm{E}+00$ \\
\hline & TENAGA KERJA & $1,51 \mathrm{E}+00 * *$ \\
\hline & \multicolumn{2}{|c|}{ BUNGA MODAL SENDIRI (Rp)-3,98E+00 } \\
\hline & Konstan & $1,12 \mathrm{E}+07$ \\
\hline & $\mathrm{R}^{2}$ & 0,6693 \\
\hline
\end{tabular}

Penerimaan(revenue)petanicenderung akan meningkat jika terdapat penambahan input meskipun akan mendorong terjadinya kenaikan biaya. Sebaliknya penambahan input tersebut cenderung akan menurunkan pendapatan (income) petani. Hasil analisa regresi menunjukkan bahwa peningkatan sewa lahan, pemberian pestisida dan 
tenaga kerja cenderung akan meningkatkan penerimaan petani; sebaliknya, penambahan bibit, pupuk, tenaga kerja akan menekan pendapatan petani.

\section{Hasil Analisis dengan Mempergunakan Model Saraf Buatan}

Keunggulan penggunaan model saraf buatan adalah perhitungan dapat dilakukan secara simultan yaitu input dan output yang jumlahnya lebih dari satu dapat dianalisis dalam satu waktu. Selain itu, model saraf buatan dapat dipergunakan untuk menduga fungsi-fungsi non-linier. Dalam penelitian ini, pengaruh berbagai variabel biaya (eksplisit maupun implisit) terhadap penerimaan dan pendapatan petani tebu dilakukan secara simultan.
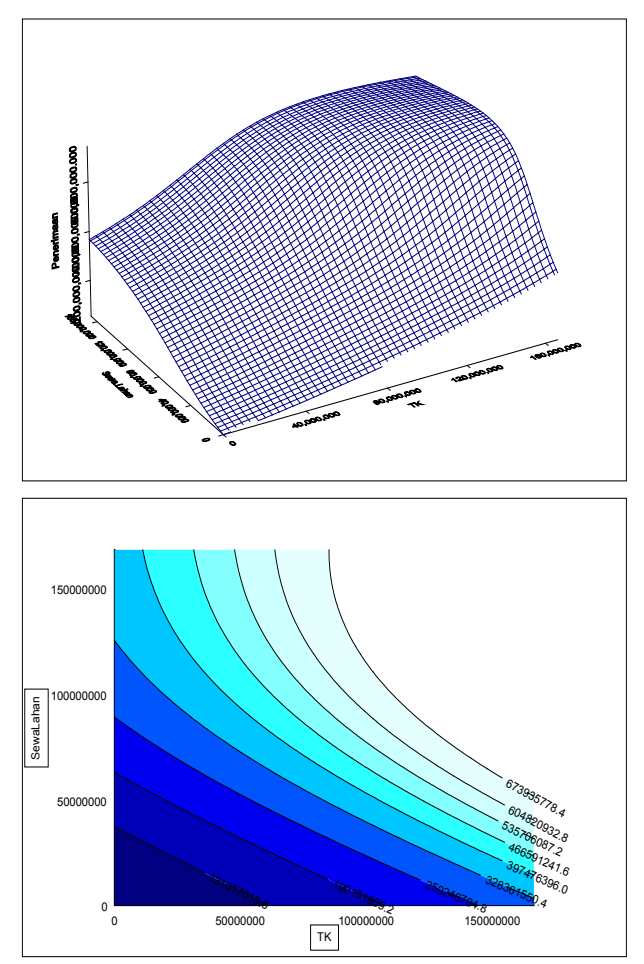

Gambar 2. Pengaruh Biaya Tenaga Kerja

(x) dan Sewa Lahan (y) terhadap Penerimaan $(\mathrm{z})$

Gambar 2 menunjukkan hubungan antara biaya sewa lahan dan biaya tenaga kerja terhadap pendapatan petani. Pada grafik kontur, warna yang lebih terang menunjukkan nilai penerimaan atau pendapatan yang lebih tinggi dibandingkan warna gelap.

Hasil yang diperoleh menunjukkan bahwa sampai batas tertentu, penambahan biaya tenaga kerja (sumbu x) dan biaya sewa lahan (sumbu y) akan mendorong terjadinya kenaikan penerimaan petani karena produksi yang meningkat meskipun dengan kenaikan yang semakin melambat. Kenaikan yang terjadi relatif bersifat gradual sehingga dalam analisis regresi linier pengaruhnyapun relatif signifikan (karena ada kesesuaian model).

Meskipun demikian, hubungan kedua variabel tersebut (biaya tenaga kerja dan sewa lahan) terhadap pendapatan petani tebu tidaklah sesederhana seperti halnya pada penerimaan petani. Gambar 3 menunjukkan hubungan antara biaya tenaga kerja (sumbu $\mathrm{x}$ ) dan biaya sewa lahan (sumbu y) terhadap pendapatan petani.
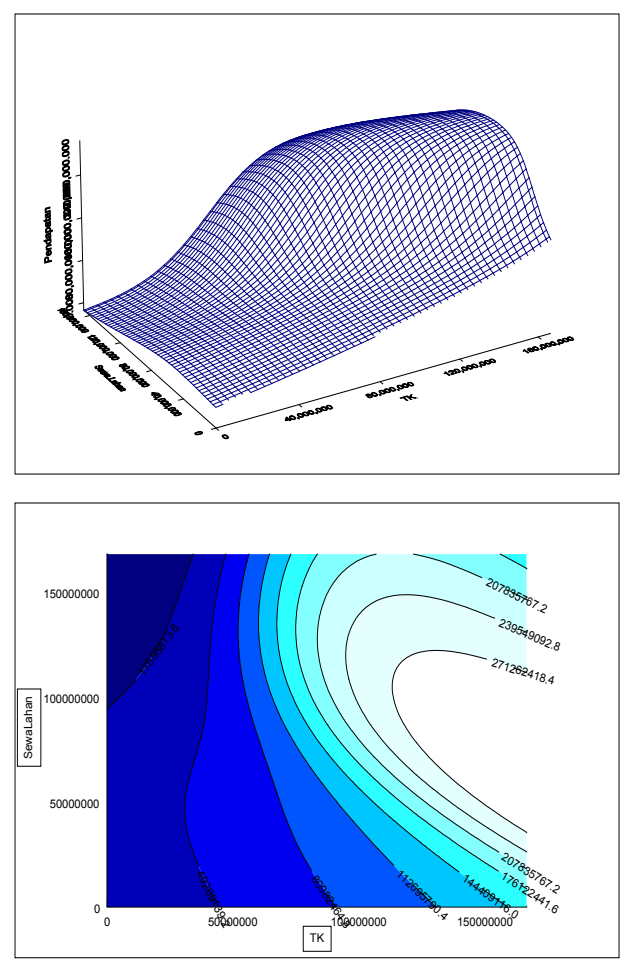

Gambar 3. Pengaruh Biaya Tenaga Kerja (x) dan Biaya Sewa Lahan (y) terhadap Pendapatan (z)

Pada Gambar 3 terlihat bahwa biaya sewa lahan yang tinggi dengan penggunaan biaya tenaga kerja rendah cenderung menekan pendapatan petani. Hal ini menunjukkan bahwa usaha tani tebu harus dilakukan secara intensif. Meskipun demikian, penambahan biaya tenaga kerja hanya akan memaksimalkan pendapatan petani pada kisaran biaya sewa lahan antara 50 sampai dengan 100 juta. Penambahan biaya sewa lahan dan tenaga kerja yang 
terlalu besar justru akan menekan pendapatan petani. Jika dilakukan analisis lebih lanjut dapat diketahui seberapa banyak tambahan biaya tenaga kerja dapat dilakukan sebelum terjadi penurunan pendapatan.

Pada analisis regresi, biaya bibit dan pupuk tidak berpengaruh nyata pada penerimaan petani. Meskipun demikian, dari hasil analisis dengan mempergunakan model saraf buatan (Gambar 4), terlihat bahwa peningkatan biaya untuk bibit (sumbu x) akan menekan penerimaan petani (khususnya ketika dilakukan pembongkaran ratoon). Penurunan terjadi secara gradual (decreasing at decreasing rate). Penurunan penerimaan sampai batas tertentu dapat ditekan dengan menambah biaya pemupukan (sumbu y). Meskipun demikian, penambahan biaya pemupukan tetap ada batasnya, karena penambahan biaya pemupukan yang terlalu tinggi akhirnya juga akan menekan penerimaan petani. Hal ini terlihat pada bentuk kurva biaya pemupukan yang berbentuk sigmoid mengikuti bentuk kurva fungsi produksi pada penerimaan petani.
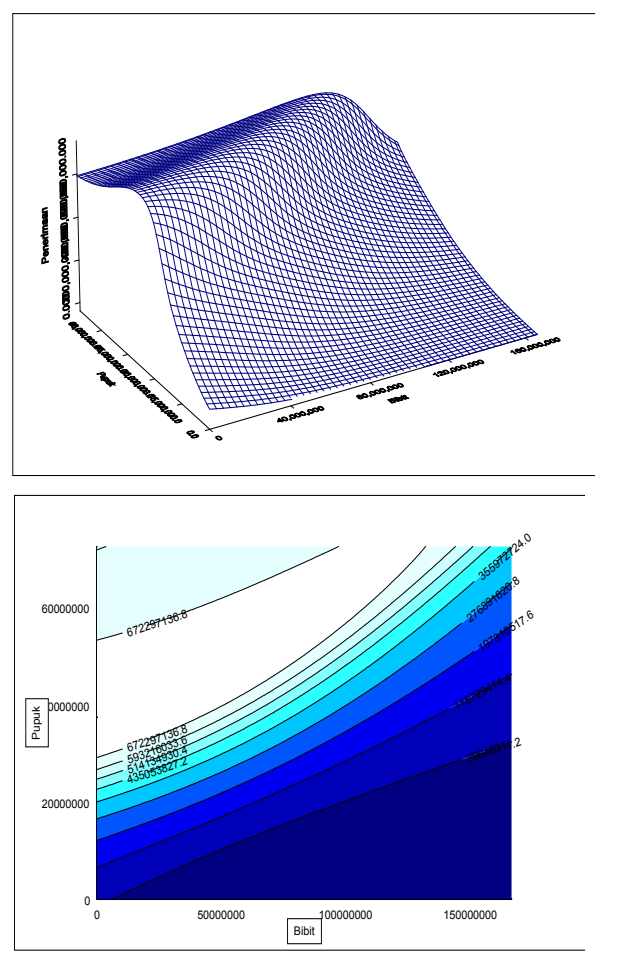

Gambar 4. Pengaruh Biaya Bibit (x) dan Pupuk (y) terhadap Penerimaan (z)
Pada analisis regresi, peningkatan biaya bibit dan pupuk secara nyata akan menurunkan pendapatan petani (dan sebaliknya).

Gambar 5 menunjukkan analisis lebih lanjut pengaruh biaya bibit (sumbu $\mathrm{x}$ ) dan pupuk (sumbu y) terhadap pendapatan petani. Penambahan biaya pupuk yang terlalu besar justru akan menekan pendapatan petani. Penambahan biaya pupuk lebih dari 50 juta di daerah penelitian cenderung akan menurunkan pendapatan petani, demikian juga penambahan biaya bibit lebih dari 50 juta akan memberikan pengaruh yang sama.
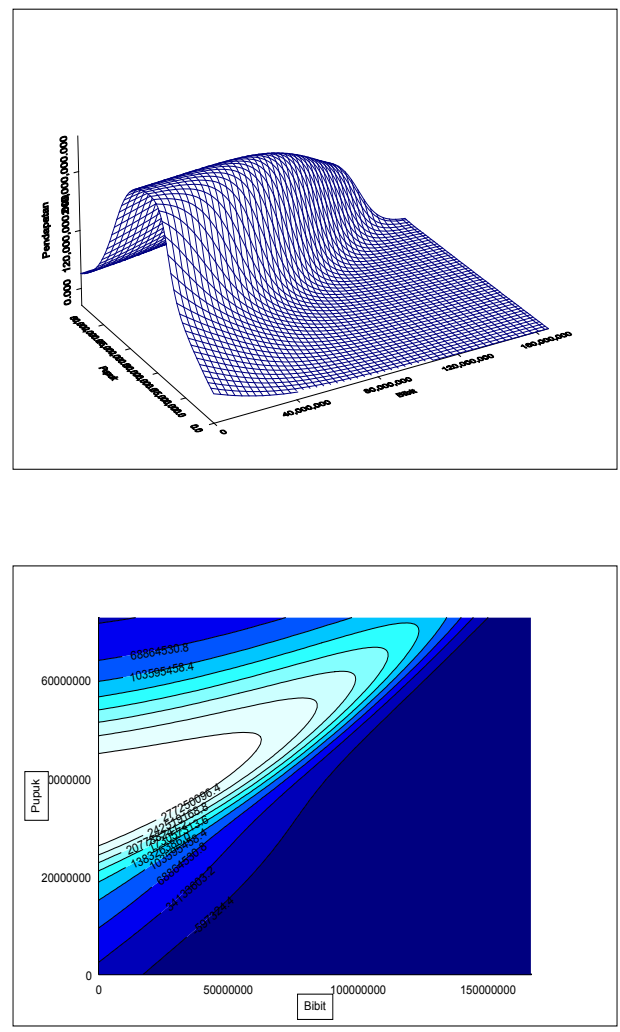

Gambar 5. Pengaruh Biaya Bibit (x) dan Pupuk (y) terhadap Pendapatan (z)

Pengaruh bunga pinjaman dan bunga modal sendiri terhadap penerimaan petani tebu pada analisis regresi tidak mempunyai pengaruh yang signifikan. Pada analisis dengan mempergunakan model saraf buatan, kedua variabel tersebut juga tidak berkontribusi cukup besar pada penerimaan petani. 
Meskipun demikian, Gambar 6 menunjukkan pengaruh keduanya dalam batas tertentu akan meningkatkan penerimaan petani. Besarnya bunga modal sendiri di bawah 50 juta dan bunga pinjaman di bawah 75 juta akan menurunkan penerimaan petani. Kondisi ini menunjukkan bahwa usaha tani tebu membutuhkan modal yang cukup besar.
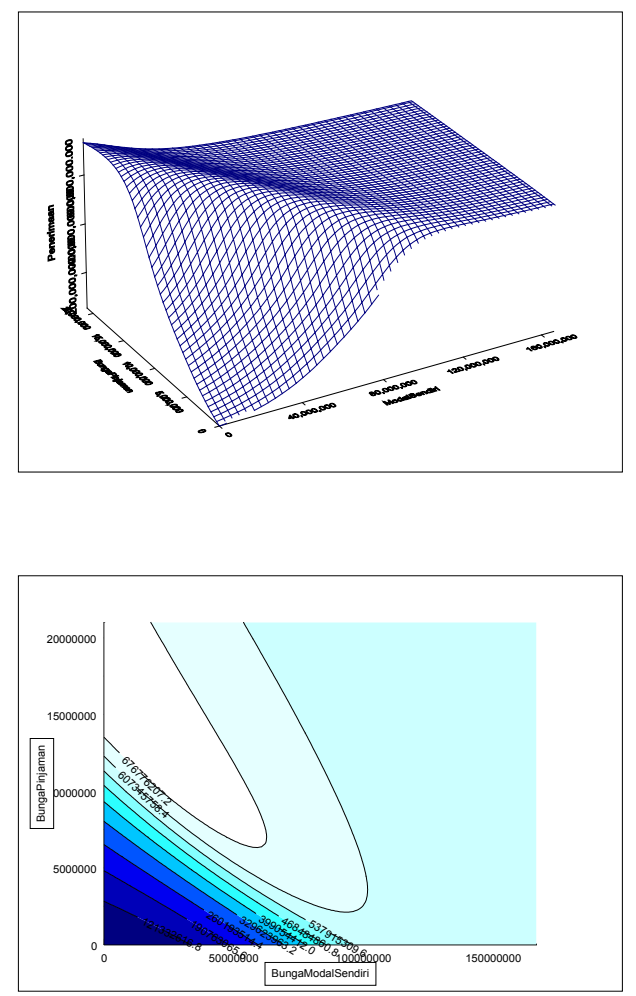

Gambar 6. Pengaruh Bunga Modal Sendiri (x), Bunga Pinjaman (y) terhadap Penerimaan $(\mathrm{z})$

Pengaruh bunga modal sendiri dan bunga pinjaman terhadap pendapatan petani, baik dari analisis regresi maupun model saraf buatan, seperti halnya pada penerimaan petani, juga tidak nyata atau mempunyai kontribusi yang kecil.

Secara umum, Gambar 7 menunjukkan bahwa bunga modal sendiri (sumbu $\mathrm{x}$ ) cenderung lebih menekan pendapatan petani, sedangkan bunga pinjaman (sumbu y) dalam batas tertentu dapat meningkatkan pendapatan petani, khususnya petani dengan beban bunga modal sendiri relatif kecil. Meskipun demikian, jika kedua pinjaman ini terlalu besar akan sangat membebani petani.
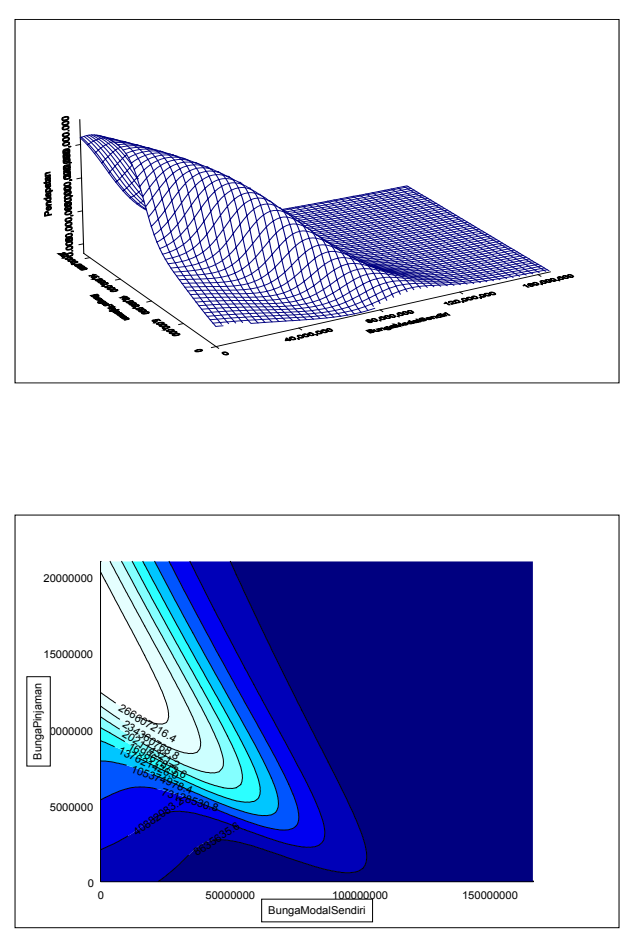

Gambar 7. Pengaruh Bunga Modal Sendiri (x), Bunga Pinjaman (y) terhadap Pendapatan (z)

Selajutnya, hasil analisia regresi menunjukkan bahwa penambahan biaya pestisida akan meningkatkan penerimaan petani sedangkan pada pupuk tidak berpengaruh signifikan pada penerimaan petani.

Hasil analisis dengan mempergunakan model saraf buatan (Gambar 8) juga menunjukkan bahwa penambahan biaya pestisida memberikan kontribusi cukup besar, baik pada penerimaan maupun pendapatan petani (Tabel 1). Meskipun demikian, hasil analisis dengan mempergunakan model saraf buatan menunjukkan bahwa kenaikan tersebut hanya terjadi pada wilayah (range) yang sempit. Pada penerimaan petani tebu terjadi levelling off karena penambahan biaya pestisida tidak akan menambah lebih jauh penerimaan petani. Kondisi ini semakin nyata pada saat pemberian pupuk semakin besar. Oleh karena itu, kecenderungan belanja pupuk dan pestisida secara berlebihan tidak akan memberikan kontribusi pada penerimaan petani tebu. 

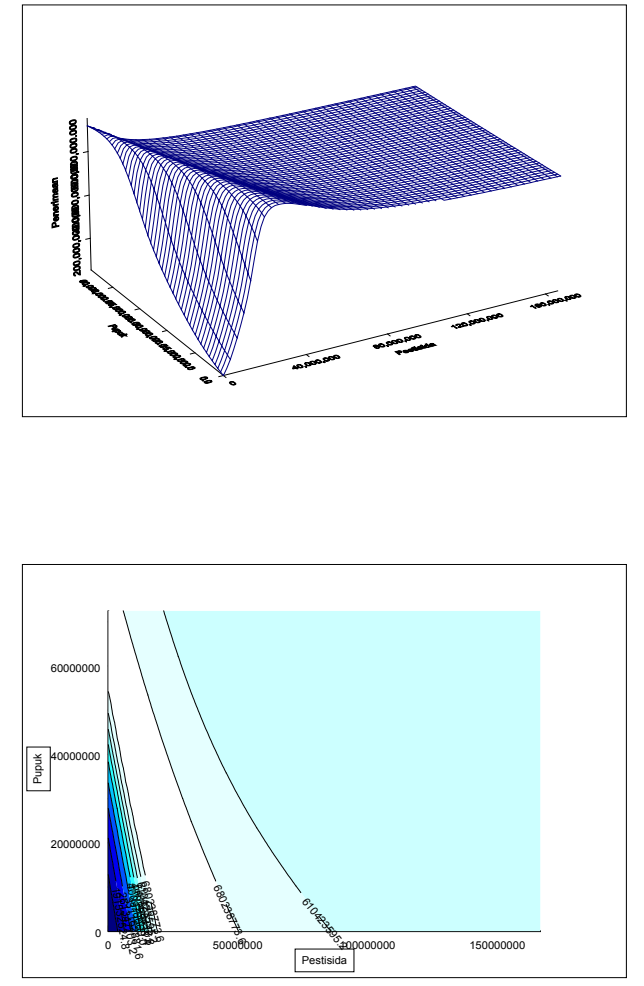

Gambar 8. Pengaruh Biaya Pestisida (x), Biaya Pupuk (y), terhadap Penerimaan $(\mathrm{z})$

Untuk pendapatan petani, hasil analisis regresi menunjukkan bahwa biaya pupuk yang semakin besar akan menurunkan pendapatan petani secara signifikan, sedangkan biaya pestisida tidak berpengaruh nyata pada pendapatan petani.

Gambar 9 menunjukkan pengaruh tambahan biaya pestisida (sumbu x), biaya pupuk (sumbu y) dan pendapatan petani tebu (sumbu z) dengan mempergunakan model saraf buatan. Hasil yang diperoleh menunjukkan bahwa tambahan biaya pupuk jika tanpa disertai dengan tambahan pestisida yang memadai akan dengan cepat menekan pendapatan petani. Meskipun demikian, secara umum pembiayaan pupuk maupun pestisida secara berlebihan cenderung akan menekan pendapatan petani. Berbagai hasil yang diperoleh menunjukkan bahwa meskipun usaha tani tebu bersifat intensif, pemakaian input secara berlebihan seperti pestisida serta pupuk dan bunga pinjaman maupun bunga modal sendiri akan menekan pendapatan petani tebu.
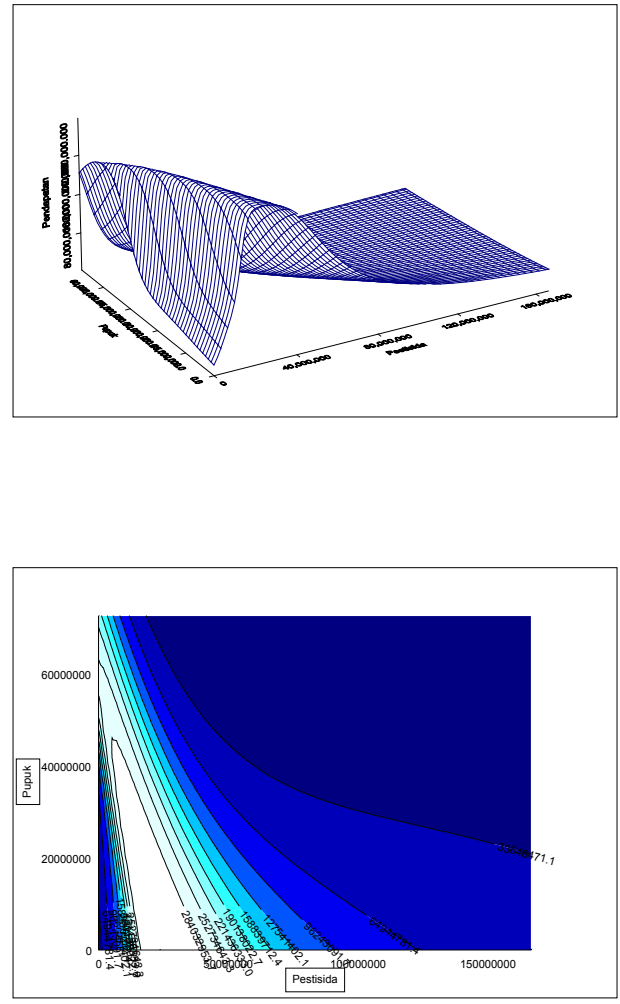

Gambar 9. Pengaruh Biaya Pestisida

(x), Biaya Pupuk (y) tehadap Pendapatan (z)

Penggunaan model saraf buatan dapat digunakan untuk menduga fungsi-fungsi yang bersifat non linier dengan jumlah data yang sangat besar. Dalam tulisan diilustrasikan secara jelas bagaimana pola pengaruh biaya eksplisit maupun implisit terhadap penerimaan dan pendapatan petani tebu dengan melakukan perhitungan secara simultan bagi kedua variabel tersebut. Meskipun demikian, model ekonometrika masih mempunyai keunggulan dibandingkan model saraf buatan jika dipakai dalam analisis yang terkait dengan interpretasi ekonomi meskipun terdapat resiko pada kesalahan spesifikasi model.

\section{SIMPULAN}

Hasil analisa regresi menunjukkan bahwa peningkatan sewa lahan, pemberian pestisida dan tenaga kerja cenderung akan meningkatkanpenerimaanpetani; sebaliknya, penambahan bibit, pupuk, tenaga kerja akan menekan pendapatan petani. Selanjutnya, hasil analisis dengan mempergunakan model saraf buatan menunjukkan bahwa 
sewa lahan, bibit, pestisida dan tenaga keja memiliki kontribusi yang besar baik pada penerimaan dan pendapatan petani. Hasil analisis dengan mempergunakan model saraf buatan menunjukkan bahwa biaya sewa lahan yang tinggi dengan penggunaan biaya tenaga kerja rendah cenderung menekan pendapatan petani, sehingga usaha tani tebu harus dilakukan secara intensif. Selanjutnya, penambahan biaya pupuk dan bibit yang terlalu besar justru akan menekan pendapatan petani. Secara umum, bunga modal sendiri cenderung lebih menekan pendapatan petani, sedangkan bunga pinjaman dalam batas tertentu dapat meningkatkan pendapatan petani, khususnya petani dengan beban bunga modal sendiri relatif kecil.

\section{SARAN}

Penelitian dan penggunaan model saraf buatan dalam bidang pertanian perlu ditingkatkan, karena cukup banyak analisis dalam bidang pertanian yang merlukan data yang sangat besar dan bersifat non linier. Pola fluktuasi harga komoditas pertanian, karakteristik petani. Penelitian lanjutan yang dapat dilakukan misalnya menetukan titik maksimum/minimum global ataupun memasukkan variabel produktivitas dalam penelitian.

\section{DAFTAR PUSTAKA}

Carpio, K. J. E. dan Hermosilla, A. Y. 2000. On Multicolliniearity and Artificial Neural Network. Manila: Dept of Mathematics, University of Philipines.

Jain, A. K., Mao, J. dan Mohiudin, K. 1998. Artificial Neural Network: A Tutorial. Michigan: Michigan State University.

Krose, B. dan van der Smagt, P. 1996. An Introduction to Neural Network. Amsterdam: Faculty of Mathematics and Computer Science, University of Amsterdam.

Sima, J. 1998. Introduction to Neural Networks Technical Report No. V-755. Prague: Institute of Computer Science, Academy of Sciences of the Czech Republic.

Tan, C. 1997. An Artificial Neural Networks Primer with Financial Applications Examples in Financial Distress Predictions and Foreign Exchange Hybrid Trading System. Gold Coast: Bond University 